\title{
TRANSLATION AND VALIDATION INTO THE BRAZILIAN PORTUGUESE OF THE RESTLESS LEGS SYNDROME RATING SCALE OF THE INTERNATIONAL RESTLESS LEGS SYNDROME STUDY GROUP
}

\author{
Alice H. Masuko', Luciane B.C. Carvalho', Marco A.C. Machado3, \\ José F. Morais ${ }^{4}$, Lucila B.F. Prado ${ }^{5}$, Gilmar F. Prado ${ }^{6}$
}

\begin{abstract}
Background: Restless legs syndrome (RLS) is a chronic sensory-motor disorder characterized by unpleasant limb sensations and an irresistible urge to move. The International Restless Legs Syndrome Study Group developed the Restless Legs Syndrome Rating Scale (IRLS) to assess the severity of RLS symptoms. The objective of this study was to translate and validate the IRLS into Brazilian Portuguese. Method: The IRLS was translated into Brazilian Portuguese, analyzed, back translated to English, and compared to the original version. It was applied to 10 patients for cultural verification. The language was adjusted and the final version was administered to 30 patients ( 13 male, mean age $58.88 \pm 14.82$ ). Results: There was correlation among the IRLS evaluation of three experts. Many linguistic adaptations were required to achieve cultural adequacy and the Cronbach's alpha coefficient showed reliability of $80 \%$. Conclusion: IRLS was translated, adapted, and validated to Brazilian Portuguese language, showing good reliability and validity.
\end{abstract}

KEY WORDS: restless legs syndrome, scale, severity, validation.

Tradução e validação para a língua portuguesa da escala de graduação da síndrome das pernas inquietas do Grupo Internacional do Estudo da Sindrome das Pernas Inquietas

Resumo - Introdução: A sindrome das pernas inquietas (SPI) é uma doença crônica, sensório-motora, caracterizada por sensações desagradáveis nos membros e uma urgência em movimentá-los. O Grupo Internacional de Estudos da Síndrome das Pernas Inquietas desenvolveu a Escala de Graduação da Síndrome das Pernas Inquietas (EGSPI) para avaliar a gravidade dos sintomas da SPI. Objetivo: Traduzir, adaptar culturalmente e validar a EGSPI para o português do Brasil. Método: A escala foi vertida para o português, analisada, vertida novamente para o inglês e comparada com a versão original. Foi aplicada em 10 pacientes para adequação cultural. A linguagem foi ajustada e a versão final foi aplicada em 30 pacientes (13 homens, idade média de $58,88 \pm 14,82$ ). Resultados: Houve correlação da aplicação da escala entre três avaliadores. Foram necessárias adaptações lingüísticas para adequação cultural e o alfa de Chronbach mostrou confiabilidade de $80 \%$. Conclusão: A EGSPI foi traduzida, adequada e validada para o português do Brasil, com boa validade e confiabilidade.

PALAVRAS-CHAVE: síndrome das pernas inquietas, escala, gravidade, validação.

Restless legs syndrome (RLS) is very prevalent, and maybe as high as $10 \%$, but yet many health care providers remain unaware of this syndrome ${ }^{1-7}$. Thomas Willis, who reported restlessness, tossing of arms and legs, first described RLS in 1685, and that patients were unable to sleep well. In 1995, the International Restless Legs Syndrome Study Group (IRLSSG) published standard international criteria for the diagnosis of RLS, in a bid to develop future collaborations in international research ${ }^{8,9}$. This Group developed a rating scale for measuring both severity and impact of the disorder, comprising 10 questions ${ }^{10}$.

The RLS is a chronic disease, with subjective manifestations, unpleasant sensory sensations such as paresthesia or dysesthesia, an intense, irresistible urge to move

Federal University of São Paulo, São Paulo SP, Brazil (UNIFESP): 'MD, Neuro-Sono section, Department of Neurology; ${ }^{1}$ PhD, Neuro-Sono section, Department of Neurology; ${ }^{3}$ DDO, PhD, Neuro-Sono section, Department of Neurology; ${ }^{4}$ Statistician, Department of Medicine; ${ }^{5} \mathrm{MD}$, PhD, Neuro-Sono section, Hospital São Paulo Sleep Laboratory, Discipline of Neurology; ${ }^{6} \mathrm{MD}$, PhD, Professor of Neurology, Department of Medicine, Hospital São Paulo Sleep Laboratory, Neuro-Sono section, Discipline of Neurology.

Received 17 July 2008, received in final form 24 September 2008. Accepted 9 October 2008.

Dr. Gilmar F. Prado - Rua Claudio Rossi 394 - 01547-000 São Paulo SP - Brasil. E-mail: gilmarunifesp@yahoo.com.br 
the legs with worsening of symptoms at rest and relief upon motor activation. The symptoms also worsen in the evening or at night. Other clinical features of RLS include sleep disorders and their consequences, periodic limb movements during sleep and wakefulness. The disease may develop into a crisis or in a progressive way. In $40 \%$ to $50 \%$ of cases there is a familial trace with autosomal dominant inheritance $e^{8,9}$.

In Brazil, no epidemiological reports on the prevalence of RLS are yet available. Some studies suggest that prevalence does not vary significantly between populations of the USA and Western Europe. The sleep center Neuro-Sono and the Brazilian association of RLS - Associação Brasileira da Síndrome das Pernas Inquietas (ABRAS$\mathrm{PI}$ ), recently founded, have contributed to our knowledge on RLS. Thus, it is vital to have an instrument with international validation, that can be applied in the Brazilian Portuguese to rate RLS severity, besides the John Hopkins criteria", with good correlation with the IRLS of IRLSSG.

The objective of this report is to translate, achieve cultural equivalence for, and validate the IRLS while assessing its internal consistency in patients diagnosed with RLS, according to gender, age, and the items of the scale.

\section{METHOD}

\section{Rating scale for RLS}

The IRLSSG developed the IRLS for measuring the disease severity based on 10 questions with a similar format and polarity. Each question has a set of five response options, varying from score 0 (no impact) to 4 (very severe). A total score ranges from 0 to 40.

Following the Mapi Research Institute instructions ${ }^{12}$ the scale was translated from English into Brazilian Portuguese by two independent translators fluent in English and with knowledge on sleep disorders. This process resulted in two forward translations: versions 1 and 2 . The translators discussed the translations and the consensus resulted in a reconciled version (version 3). Subsequently, an English translator translated the reconciled version into the English language, resulting in back translation (version 4).

Finally, the English back translation was compared with the original English Rating Scale resulting in the version 5 administered to 10 patients with RLS to verify whether it was acceptable and understandable.

After patients had answered the questions, they were invited to discuss any difficulties and suggest changes, resulting in a final version (version 6).

\section{Population}

The final version of the IRLS was administered between September 2004 and February 2005 to 30 new patients. They were 17 female, aged from 18 to 81 years, diagnosed as having RLS by two neurologists. They were outpatients from the Neuro-Sono section of the Department of Neurology of the Federal Universi- ty of São Paulo (UNIFESP). The Ethics Committee of the UNIFESP approved the project and the included patients who all had a diagnosis of RLS and assigned an informed consent. Patients who were unable to complete the questionnaire for any reason, such as dementia, aphasia or illiteracy were excluded. Reliability and validity were then determined.

\section{Statistical analysis}

A descriptive analysis was performed considering the following parameters: age, gender, IRLS individual items, and IRLS score using mean \pm standard deviation (SD) for continuous variables with normal distribution, and $\mathrm{n}(\%)$ for nominal variables ${ }^{13}$. We calculated the $95 \%$ confidence interval $(\mathrm{Cl})$ for evaluating the continuous measures precision. For evaluating the reliability of IRLS we used the Cronbach's alpha coefficient ${ }^{14,15}$. Despite the ordinal character of IRLS indicators, we used the Spearman correlation coefficient for evaluating the criterion validity. In this case we consider as criterion the opinion of three experts that evaluated the patients according to Johns Hopkins criteria for RLS severity" and their consensus. If there was not a consensus we considered the worst assessment. The SPSS for windows ${ }^{\circledR}$ v.13.0 was used for all analyses. Correlations $p<.05$ were considered statistically significant.

\section{RESULTS}

Translation and cultural adaptation

Instructions and questions - We modified some wording and sentence constructions to adapt the text to the Brazilian cultural pattern, aiming to improve clarity and objectivity (Table 1). The words in each question were adapted to the habitual form and use of the Portuguese of Brazil, and some grammatical improprieties were necessary for a better understanding of the expressed contents, which resulted in a more informal Portuguese.

Some words took on an almost literal version and were understandable for most patients. After giving version 5 to 10 patients with RLS, we modified some words (Table 1) to compose final version - version 6.

In questions 1 and 5, the word "severe" was translated into "intenso" (intense) to mean intensity and not severity as in the English language. In questions 4 and 9, "how severe" was translated into "qual a intensidade" (how intense) (Table 1). In question 2 the term "severe" was translated into "grande" (big) and its meaning were well understood as we expected. In question 6, "how severe" was translated into "qual gravidade" to mean disease severity. In question 8, "how severe" was considered a temporal concept, "qual a duração" (how long), which better represented its sub-alternatives, showing adequate internal validity within the questionnaire (Table 1). At first, the term "rate" was translated as "graduar", but during the administration of version 2 the patients considered it as graduation in a mathematical sense, so we used the term "consid- 
Table 1. Terms of the original English version that had to be adapted in the final Brazilian Portuguese version, and the correspondent meaning in English, again.

\begin{tabular}{|c|c|c|}
\hline Item & Original english & $\begin{array}{c}\text { English } \\
\text { (Final version) }\end{array}$ \\
\hline Instruction & Rate & Answer \\
\hline \multirow[t]{4}{*}{ Q1 } & Rate & To consider \\
\hline & & To take in account \\
\hline & Severe & Intense \\
\hline & Mild & Light \\
\hline \multirow[t]{4}{*}{ Q2 } & Rate & To consider \\
\hline & & To take in account \\
\hline & Severe & Big \\
\hline & Mild & Small \\
\hline \multirow[t]{2}{*}{ Q3 } & Slight relief & Little relief \\
\hline & Complete & Total \\
\hline \multirow[t]{2}{*}{ Q4 } & How severe & How intense \\
\hline & Mild & Light \\
\hline Q5 & Severe & Intense \\
\hline Q6 & How severe & How severe \\
\hline Q7 & None & Never \\
\hline Q8 & How severe & How long \\
\hline \multirow[t]{3}{*}{ Q9 } & How severe & How intense \\
\hline & & What is the intensity \\
\hline & Carrying out a satisfactory & Activities \\
\hline \multirow[t]{5}{*}{ Q10 } & Angry & Anger \\
\hline & Depressed & Depression \\
\hline & Sad & Sadness \\
\hline & Anxious & Anxiety \\
\hline & Irritable & Irritability \\
\hline
\end{tabular}

$\mathrm{Q}$, question.

Table 2. Distribution of patients by age and gender.

\begin{tabular}{cccc}
\hline Age, years & Male $(n=13)$ & Female $(n=17)$ & Total $(n=30)$ \\
\hline Mean \pm SD & $57.54 \pm 12.13$ & $58.88 \pm 14.82$ & $58.30 \pm 13.51$ \\
$95 \% \mathrm{Cl}$ & 45.46 to 67.92 & 52.29 to 60.77 & 53.25 to 63.34 \\
Range & $33-79$ & $18-81$ & $18-81$ \\
\hline
\end{tabular}

$\mathrm{SD}$, standard deviation; $\mathrm{Cl}$, confidence interval. erar", which corresponds to "take into account, to consider" for better understanding. We adopted the term "considerar" in the translation of "rate" (Table 1), but in the Instructions we used "responder" (answer).

The word "mild" was translated as "leve" according to the meaning of rating implicit in the options of questions 1 and 4. In question 2, "mild" was translated into "pequeno" (small) and not "suave" (light) after the administration of version 2, to enable better understanding of the question. Although the term "pequeno" is not very formal, it was well understood and we therefore decided to adopt it in the final version. The term "slight relief" was translated to "pequeno alivio" (little relief) and was well understood. In question 3, the term "complete" could be translated into "completo", but we adopted the word "total", which would be well understood across all cultural levels.

In question 7, we did not use the terms related to the rating of intensity associated to frequency, but maintained only the terms related to the periodicity of the symptoms so as not to compromise answers (Table 1). Continuing this approach we translated "none" (nenhum modo) as "nunca" (never) to give an idea of time raised in the sequence of options in question 7. In question 9 we substituted the expression "carrying out a satisfactory" by "atividades" (activities) to provide a better understanding in relation to items of question 9. In question 10, we replaced the English adjectives that express changes of mood by equivalent nouns in Brazilian Portuguese, because they were clearer.

Patient characteristics - There were 13 male patients (43.3\%) aged 33 to 79 years, mean age $57.54 \pm 12.13, \mathrm{Cl} 45.46$ to 67.92 (Table 2). The 17 female patients (56.7\%) aged 18 to 81 years, mean age $58.88 \pm 14.82$, IC 52.29 to 60.77 . In this sample, the patients' age varied from 18 to 81 and the mean was $58.30 \pm 13.51$, IC 53.25 to 63.34 . We did not observe significant difference between mean age for all patients ( $\mathrm{p}>.05)$.

Table 3. Matrix of ordinal correlations (Spearman) among scale questions (q).

\begin{tabular}{|c|c|c|c|c|c|c|c|c|c|c|}
\hline & $\mathrm{q} 1$ & $\mathrm{q} 2$ & $q^{3}$ & $\mathrm{q} 4$ & q5 & q6 & q7 & q8 & q9 & q10 \\
\hline $\mathrm{q} 1$ & 1.00 & $.42^{*}$ & .27 & $.68^{* *}$ & .09 & $.78^{* *}$ & .06 & $.37^{\star}$ & $.39 *$ & $.58^{\star *}$ \\
\hline q2 & $.42^{*}$ & 1.00 & -0.32 & .28 & .28 & $.40^{*}$ & .00 & .25 & .14 & .30 \\
\hline q3 & .27 & -.03 & 1.00 & .12 & .29 & .17 & -.06 & .28 & .28 & .23 \\
\hline q4 & $.68^{\star *}$ & .28 & .12 & 1.00 & .19 & $.69 * *$ & .26 & $.49 * *$ & $.56^{* *}$ & $.50 * *$ \\
\hline q5 & .09 & .28 & .29 & .19 & 1.00 & .12 & .19 & .30 & .28 & $.38^{*}$ \\
\hline q6 & $.78^{* *}$ & $.40^{*}$ & .17 & $.69 * *$ & .12 & 1.00 & .26 & $.47^{\star *}$ & $.66^{* *}$ & $.62^{\star *}$ \\
\hline q7 & .06 & .00 & -.06 & .26 & .19 & .26 & 1.00 & $.49^{\star *}$ & $.45^{\star}$ & .25 \\
\hline q8 & $.37^{\star}$ & .25 & .28 & .49 ** & .30 & $.47^{\star *}$ & $.49^{\star *}$ & 1.00 & $.42^{*}$ & $.39 *$ \\
\hline q9 & $.39 *$ & .14 & .28 & $.56^{* *}$ & .28 & $.66^{* *}$ & $.45^{*}$ & $.42^{*}$ & 1.00 & $.46^{* *}$ \\
\hline q10 & $.58^{* *}$ & .30 & .23 & .50 ** & $.38^{*}$ & $.62^{\star *}$ & .25 & $.39 *$ & $.46^{\star *}$ & 1.00 \\
\hline
\end{tabular}

*Correlation is significant at .05; ${ }^{* *}$ Correlation is significant at .01 . 
Table 4. Cronbach's alpha coefficients for all questions (q) together, and by excluding each one, and the correlation of each question with as the remaining together.

\begin{tabular}{ccc}
\hline $\begin{array}{c}\text { Excluded } \\
\text { question }\end{array}$ & $\begin{array}{c}\text { Corrected correlation } \\
\text { of one question and } \\
\text { the remaining }\end{array}$ & $\begin{array}{c}\text { Cronbach's alpha } \\
\text { coefficient excluding } \\
\text { one question }\end{array}$ \\
\hline- & - & .83 \\
q1 & .63 & .80 \\
q2 & .35 & .83 \\
q3 & .19 & .84 \\
q4 & .65 & .78 \\
q5 & .35 & .83 \\
q6 & .77 & .79 \\
q7 & .37 & .83 \\
q8 & .60 & .80 \\
q9 & .63 & .80 \\
q10 & .65 & .79 \\
\hline
\end{tabular}

\section{Validation of the scale}

Reliability - The reliability analysis of the 10-question scale based on Bowling instructions, showed a predominance of statistically positive correlations $(p<.05)$ in each question (Table 3). In the version 6 of the scale the Cronbach's alpha analysis disclosed values around $80 \%$. It is noteworthy that the exclusion of any question of scale did not introduce gain in internal consistency (Table 4).

Validity of the scale - The traditional definition of criterion validity is the correlation of a scale with another measure of the analyzed characteristic, ideally a 'gold standard'. In this study we consider the opinion of three experts skilled in the use of the Johns Hopkins severity scale and their consensus as criterion. The Johns Hopkins severity scale is an easy and highly reproducible tool, and was chosen as an external criterion. The results show significant correlation among IRLS score and expert 1 ( $r=.519$, $p=.003)$, expert $2(r=.438, p=.016)$, expert $3(r=.448, p=.013)$, and the expert consensus $(r=.44, p=.015)$.

\section{DISCUSSION}

The IRLS of the IRLSSG was adapted and validated to the Portuguese language of Brazil. It was necessary to modify some words and sentences. The IRLS was administered to 30 patients and demonstrated internal consistency and proved an adequate instrument to rate RLS in Brazilian patients. Some alterations were related to education level of the Brazilian population. The INAF, the National Indicator of Functional Literacy showed that, in 2005 , Brazil illiteracy rate was $7 \%$, whereas rudimentary literacy was $30 \%{ }^{16}$. According to the classification of the INAF, the rudimentary literacy population can understand a simple item of information contained in one statement, therefore calling for careful devising of the requests. The questionnaire was devised with intelligible sentences that could be understood by the majority of the population. We avoided sentence constructions that could be understood only by a more educated population, explaining why we committed some minor grammatical errors ${ }^{17}$.

The term "graduar" (rate), for example was not understood properly in the administration of version 1 ; hence, we replaced it by "responder" (answer) without losing the idea of graduation, which is implicit in the options of each question (Table 1). This process is inherent to adaptation of questionnaires into another language. We chose not to use the abbreviation RLS in the questionnaire SPI in Brazilian Portuguese, because it is, in general, not used informally. We did not refer to diseases with abbreviations during the interview with the patients. Only health professionals use such abbreviations ${ }^{18}$.

Some cultural and linguistic characteristics were adapted in the questionnaire. For example, for the term "severe", the best translation into Brazilian Portuguese is "grave", but we adopted the term "qual intensidade" or intenso" (how intense or intense), because in the administration of version 1 many patients did not consider their symptoms as severe even when they were intense. It seems that the concept of disease severity in Brazil represents other aspects, such that a worsening in quality of life is not understood as severe (it is not life threatening). The term "severe" in English has the meaning of "intense" but in the Brazilian Portuguese language it is not common, besides a possible meaning. For cultural and educational reasons ${ }^{19-22}$, we keep this meaning (intense) just in the question 6 aiming to measure the impact of the RLS as a whole, where it was cultural and linguistically appropriate.

We concluded that by following all the formal procedures of version, cultural adaptation and validation in a sample of outpatients with RLS, in the Neuro-Sono section of the Department of Neurology of UNIFESP, we were able to devise a questionnaire (Escala de Graduação da Sindrome das Pernas Inquietas) with internal and external validity for rating the RLS according to the requirements of IRLSSG.

A complete version of this article with the final version of the restless legs syndrome rating scale you can find at www.sindromedaspernasinquietas.com.br

\section{REFERENCES}

1. Trenkwalder C, Walters AS, Hening W. Periodic limbs movements and restless legs syndrome. Neurol Clin 1996;14:629-650.

2. Culebras A. Restless legs syndrome and periodic limb movements of sleep. In Culebras A (ed). Clinical handbook of sleep disorders. Boston: Butterworth-Heinemann, 1996:251-256. 
3. Rothdach AJ, Trenkwalder C, Haberstok J, Keil U, Berger K. Prevalence and risk factors of RLS in elderly population. Neurology 2000;54: 1064-1068.

4. Prado GF. Síndrome das pernas inquietas: há quanto tempo é ignorada? Rev Neurocienc 2002;10:38-43.

5. Montplaisir J, Nicolas A, Godbout R, Walters AS. Restless legs syndrome and periodic limb movement disorder. In Krigger MH, Roth T, Dement WC (eds). Principles and practice of sleep medicine. 3.Ed. Philadelphia: WB Saunders Company, 2000:742-752.

6. Phillips B, Young T, Finn L, Asher K, Hening WA, Purvis C. Epidemiology of restless legs symptoms in adults. Arch Intern Med 2000;160: 2137-2141.

7. Allen RP, Picchietti D, Hening WA, Trenkwalder C, Walters AS. Restless legs syndrome: diagnostic criteria, special considerations, and epidemiology. A report from the restless legs syndrome diagnosis and epidemiology workshop at the National Institute Health. Sleep Med 2003,4:101-119.

8. Walters AS, Group Organizer and Correspondent. Toward a better definition of the restless legs syndrome. Mov Disord 1995;5:634-642.

9. The International Restless Legs Syndrome Study Group. Validation of the International Restless Legs Syndrome Study Group rating scale for restless legs syndrome. Sleep Med 2003;4:121-132.

10. Zucconi M, Ferini-Strambi L. Epidemiology and clinical findings of restless legs syndrome. Sleep Med 2004;5:293-299.

11. Allen PA, Earley CJ. Validation of the Johns Hopkins of restless legs severity scale. Sleep Med 2001:239-242.

12. Linguistic validation of a Quality of Life Questionnaire. Mapi Res Inst 2002. In: http: / / mapi-research-inst.org
13. Lang T. Twenty statistical errors even you can find in biomedical research articles. Croat Med J 2004;:361-370.

14. Cronbach IJ. Coefficient alpha and the internal structure of test. Psychometrika 1951;297-334.

15. Bowling A. Measuring health-a review of quality of life measurent seals. 2.Ed. BucKmghan Open University Press, 1997:9-15.

16. INAF - Indicador de analfabetismo Funcional (Internet address). Instituto Paulo Montenegro (12/05/2006). In: http: / / www.ipm.org.br/ an_ind.php

17. Correia de Campos C, Manzano G M, Bannwart de Andrade L, Castelo Filho A, Nóbrega JAM. Tradução e validação do questionário de avaliação de gravidade dos sintomas e do estado funcional na síndrome do túnel do carpo. Arq Neuropsiquiatr 2003:61:51-55.

18. Diccionario de Siglas Médicas - y otras abreviaturas, epónimos y términos médicos relacionados com la codificación de las altas hospitalarias. Laguna JY, Cunat VA. Madrid: Ministerio de Sanidad y Consumo (12/05/2006). In: http:/ / www.msc.es/ estadEstudios/estadisticas / docs/diccionarioSiglasMedicas.pdf

19. Duarte LFD. Indivíduo e pessoa na experiência da saúde e da doença. Cienc Saude Col 2003;8:173-183.

20. Minayo MCS. Saúde-doença: uma concepção popular da etiologia. Cad Saude Pub 1988;4:363-381.

21. Herzlich, Claudine. Saúde e doença no início do século XXI: entre a experiência privada e a esfera pública. Physis 2004;14:383-394.

22. Duarte LFD, Leal OF. Doença, sofrimento, perturbação: perspectivas etnográficas. Rio de Janeiro: Editora Fiocruz, 1998. 